\title{
Three Decades of Working Panchayati Raj Institutions (PRIs) in Andaman and Nicobar Islands: Issues and Challenges
}

\author{
R.V. R. Murthy \\ Associate Professor, PG Deptt. Political Science, JNRM, Port Blair
}

\begin{abstract}
Panchayati Raj Institutions (PRIs) are the cornerstone of local self government and it provides democratic platform for people's participation at various levels of governance in India. PRIs have been given constitutional status through $73^{\text {rd }}$ Constitutional Amendment in 1992 to make democracy more functional at the local level and driven by citizens needs in addition to with their participation to ensure economic development, strengthen social justice and implementing Central as well as State government welfare schemes including those 29 subjects listed in the Eleventh schedule. In its present form and structure, the PRIs in Andaman and Nicobar Islands have completed three decades of existence and well entrenched with the rural life and have brought about major development in Andaman and Nicobar Islands. However, a lot remains to be done in order to further deepen decentralization and strengthen democracy at the grass root level in the absence of legislature at Union Territory level. Given the general conceptual implication, the present paper seeks to make an in-depth study of issues and challenges encounter by PRIs in Andaman and Nicobar Islands in particular.
\end{abstract}

Key Words: Governance, Participation, Gram Sabha, Zilla Parishad.

\section{INTRODUCTION}

The grass-roots units of selfgovernment have been proclaimed as the vehicles of socio-economic transformation in rural India. Effective and meaningful functioning of these bodies made our democracy a vibrant and attained name and fame worldwide. Mahatma Gandhiji's dream come true by creating every village being a republic and Panchayats having powers has been translated into reality with the introduction of the three-tier Panchayati Raj system to enlist people's participation in rural reconstruction. On April 24, 1993 is a landmark day in the history of Panchayati Raj in India as on this day the Constitution (73rd Amendment) Act, 1992 came into force to provide constitutional status to the Panchayati Raj institutions.

The Salient Features of the Act provides uniformly 3-tier system of Panchayati Raj for all the States and UTs respectively and to hold Panchayat Elections regularly every 5 years; to provide reservation of seats for Scheduled Castes, Scheduled Tribes and Women (not less than $50 \%$ ) and to appoint State Finance Commission to make recommendations as regards the financial powers of the Panchayats. Finally, District Planning Committee (DPC) to prepare draft development plan for the district by adopting holistic approach. According to the Constitutional mandates, Panchayats have been given enormous powers and authority to function as institutions of selfgovernment. The following powers and responsibilities are delegated to Panchayats to prepare Plan for economic development and social justice; implementation of schemes for economic development and social justice in relation to 29 subjects given in Eleventh Schedule of the Constitution and to levy, collect and appropriate taxes, duties, tolls and fees for financial inclusion. 
Rural people have got a noble duty to ensure that the Panchayati Raj bodies can mobilize resources from the above sources so that these bodies can work for the socioeconomic development of the areas.

The unique feature of the Panchayati Raj Act is 33\% seats are reserved for women in Panchayats at all levels. This provision is a major move towards strengthening the position of rural women. The introduction of women in sizable numbers into the Panchayati Raj has brought significant changes in the functioning of these grass-root level institutions. Involvement of women in the Panchayati Raj Institutions is expected to bring qualitative change in the matters relating to health nutrition, children welfare, family care, drinking water etc. There is a mandatory provision for reservation of seats for SC/ST in every tier of Panchayati Raj System. The reservation for SC/ST is a significant aspect for development of disadvantaged groups in the rural areas.

Over the years Panchayats have embarked upon a numerous developmental activity to strengthen weak and under privileged by providing opportunities like primary education, training, basic health services necessary for their growth and development. Panchayati Raj Institutes are also have taken measures to ensure that all the sections of the society particularly weaker section including women and girl child get adequate opportunity for developing human resource potential. Indeed, Panchayats are also playing a major role in development of human resource for weaker section by disseminating information on special development programmes for them. NGOs, Voluntary groups and local agencies are also encouraged by PRIs in effective implementation of human resource development programmes in across the country.

The most outstanding achievement of Panchayats in last three decades is Social Mobilization and Participation for Development. Panchayati Raj system has provided avenues for facilitating people's participation at the grass-root level in the following ways: Gram Sabha has provided an open forum for discussion on various village level development activities thereby ensuring people's participation; representation of weaker sections in the decision-making process and empowering rural women through an induction of $1 / 2$ reservation in the Panchayati Raj bodies are some of the highlights. Panchayati Raj Institutions have to play an effective role in the preparation of planning for socio economic development of the rural areas. Each tier has got responsibilities to plan for the socio-economic development of the rural people as per their felt need. The $73^{\text {rd }}$ constitutional Amendment Act provides for a significant devolution of power and functions to the local bodies through decentralization and peoples participation in local self-governance. Citizen's participation can therefore be understood as a forum wherein people can participate in the decision-making process and are involved in local affairs.

\section{PRIs in Andaman and Nicobar Islands: Issues and challenges}

Let me deliberate on PRIs significance for A \& $\mathrm{N}$ Islands. I will confine my presentation and representation of PRIs success and failure in the absence of legislature at Union Territory level. The Panchayati Raj Institutions in Andaman and Nicobar Islands have endured long and providing an opportunity to rural populace to take part in democratic set-up and administration.

The Union Territory of Andaman and Nicobar islands comprised of 02 Zilla Parishads, 07 Panchayat Samities and 70 Gram Panchayats as on date. Total 858 elected representative for all the above mentioned PRIs. Beside, s there is no notified Schedule Caste in this UT. Scheduled Tribes has no reservation, since the notified ST in each constituency is less than half the population required to fill seat. The Nicobarese having their own tribal 
council to deal with day to day matters. One third seats are reserved for women in each tier. Reserved seats allotted by the Election Commission by rotation to different constituencies; $1^{\text {st }} \& 3^{\text {rd }}$ year of term for Adhyaksh post of Zilla Parishad is reserved for women.

Since the Andaman and Nicobar Islands (Panchayats) Regulation came into force in 1994 following the 73rd Constitutional Amendment, these institutions receive funds from Central Government under UT budget. Panchayats are the grassroots democratic institutions and need to be further empowered through effective devolution of functions, finances and functionaries (3Fs) following the principles of subsidiarity and centrality of Panchayats. This would also ensure convergence of plethora of schemes and pooling of resources through holistic planning by Panchayats. In order to enable Panchayati Raj Institutions (PRIs) to discharge responsibility entrusted to them under Schedule XI, they require both financial and functional autonomy. PRIs receive funds mainly from three sources: (i) From Consolidated Fund of the State as per the recommendations of the SFCs; (ii) From Central Government via Centrally Sponsored Schemes (CSSs); and (iii) Grants-in-Aid as per the Central Finance Commission award. The State Finance Commission (SFC) was set up in 1996 for A \& N Islands with the objective of making specific recommendations for making the Panchayats financially viable. The recommendations of the State Finance Commission can be divided into three categories: (i) assignment of taxes, duties, levies and tolls to local bodies; (ii) sharing of revenue proceeds; and (iii) transfers on account of grant-in-aids and other financial assistance.

The mechanism for Transfer of Funds to the PRIs currently under consideration. They are PRIs submitting applications in the prescribed format with Utilization Certificate. After scrutiny, the Directorate of RD, PRIs \& ULBs submit the proposal to the A \& N Administration with the recommendation. The Administration sanctions Grant-in-Aid after getting the approval of the Administrator. Directorate of RD, PRIs \& ULBs draw the amount through cheque and forward to the each tier of PRIs directly without channelizing through District Panchayat. Generally, the PRIs have a poor fiscal base in A \& N Islands. The resource mobilisation by the PRIs is limited as the taxes like land revenue, house tax etc are managed by administrative bodies. More buoyant taxes like excise are kept out of the purview of the PRIs. Further, the responsibilities regarding collection of other taxes have been assigned to Gram Panchayats, which have no support system to levy and collect them. Over the years, UT administration devised mechanism for effective devolution of powers and proper implementation of different functions given to the three-tier Panchayat institutions, a separate budget head has been opened under different sectors such as roads, water supply, minor irrigation, agriculture and education but PRIs have paid little attention to the issues pertaining to financial autonomy and management and auditing procedures, as they are not generally aware of these issues. Incentive schemes have been suggested to provide matching grants as an incentive for PRIs to increase their resources. These are some of the ways in which the resource position of Panchayats could be strengthened. Untied grants to Panchayats by sharing of tax and non-tax revenues and the flow of programme funds to the Panchayats have been mandated. Various forms of cess on land revenues, agriculture and other fees have also been earmarked for PRIs.

It is imperative that the PRIs raise their own resources. But until such time that they are financially dependent on funds from the UT administration, these should be in the form of untied funds. The UT budget should specify the amount earmarked for district sector plan under PRI as also the distribution of this among the three tiers. It 
is suggested that $30-40 \%$ of the State's Plan can be devolved on local bodies as untied funds as it has already been done in many states.

At present only rural development programmes are being implemented through the PRIs. Under the Centrally sponsored Programmes funds flow directly from the District Rural Development Agencies (DRDAs) to the Panchayats and programme is being implemented only at village level by the Gram Panchayats. The funds may be placed at the disposal of the Panchayat Samities and Gram Panchayats by the Zilla Parishad in phases in a time bound manner. Such devolution of funds to PRIs would create greater awareness among the people and help to empower the Panchayats to plan and implement programmes of economic development and social justice at the local level in effective manner. The flow of resources to PRIs though not very substantial, at present, is likely to increase considerably in future as the UT administration committed to strengthen PRIs.

In this regard, UT administration need to evolve effective mechanism for transfer functions, functionaries, and resources as recommended by the State Finance Commission to the local bodies. The funds released to the Central Government for PRIs would be treated as earmarked funds. To encourage and to empower the PRIs, it has also been noticed that the UT administration in the name of checks and balance withhold share of PRIs, which have not been released full allocation "in trust on a non-lapsable basis". Grants which could not be released to the PRIs in the pretext of misuse and misappropriation of funds either on account of delay in allocation or for delay in transferring functions and powers to PRIs would be credited to an incentive fund which would be created in recent years. The proceeds of PRIs fund would be released to on their fiscal performance. A monitoring agency at the UT level is in place for coordination and monitoring of utilization of funds released to PRIs is functional. A UT level Monitoring Committee consist of elected PRIs members will also be constituted to review not only the progress of implementation of the scheme but also the extent of devolution of functions, functionaries and finances.

Orders have been issued in January 2002 regarding transfer to PRIs of activities pertaining to 6 departments viz Agriculture, Fisheries, Rural Roads, Rural Water Supply, Electricity and Rural Development. Most procedural issues impacting the devolution have been sorted out. Lot of money was spent and projected under various subsectors for creation of infrastructure and strengthening of PRIs in the way of construction of Panchayat Bhavans, Guest accommodations, Kanji houses, market places and community halls besides the thrust of development is in road and water sector financed with grants obtained from the Administration. Out of interior rural roads measuring about $300 \mathrm{kms}$, have been transferred to PRIs by APWD and the remaining are likely to be transferred soon. The PRIs are in the process of integrating local priorities with national goals of covering PC villages. A provision for rural water supply and to formulate the scheme for Improvement of Water Supply at rural areas prepared and is in progress. To foster quality education in rural areas, 5 Vivekananda Kendra Zilla Parishad Vidyalayas are functional and some more schools will comes across in other islands started functioning. There are 504 villages in A\&N Islands as per 2011 Census and some of them do not have irrigation facilities. Minor Irrigation plans have been prepared for its implementation in coming years. It is the endeavor of the basic minimum needs to the villagers in the rural areas for the upliftment of the living standard of the people and to ensure rapid progress of this Union Territory. For the effective system of rural governance in A \& $\mathrm{N}$ Islands, the following suggestions are provided and they are as follows: 
1. There is an urgent need to conduct elections to local bodies which are kept in abeyance since September 2020 so has to accelerate progress on the PRIs front to achieve physical results;

2. Mobilizing own revenues is an important priority for the foreseeable future, own revenues will only be a small fraction of the PRIs resources. But such revenues mobilized according to their respective capacities are critical for development of a sense of participation of ownership and accountability;

3. There needs to be absolute clarity about the 29 subjects that have been devolved to PRIs under the $11^{\text {th }}$ schedule. Beyond notifying the devolution of these functions for example agriculture and agriculture extension, the UT need to clearly demarcate the roles and responsibilities of the concerned department of the UT administration and the PRIs. Similarly, the role of the each of the three tiers of PRIs needs to be elaborated;

4. All planning, prioritizing, implementation, monitoring and auditing should be through elected bodies like Gram Panchayats, Panchayat Samities and Zilla Parishads;

5. The PRIs bodes should be given more powers to decide on the use of public land properties and resources including civic amenities. They should be consulted prior any projects are approved in their area so that can guard the very objective of institutions of selfgovernance;

6. For greater efficiency and effectiveness of the PRIs, the devolution of power to these bodies are well known. The Political struggle between elected representatives and administration is known issues should not become an obstacle in the path of PRIs reform and greater efficiency of these PRIs bodies;

7. There is need to resolve the problem of adequate number and quality of functionaries at the PRIs. The existing functionaries are very few, mostly part- time and other staff drawn largely from the UT administration on diverted capacities;

8. The issue of funds with lack of clarity in devolved functions and paucity of adequate qualified functionaries and fiscal pressure at UT level, funding for PRIs from UT budget have been inadequate and uncertain. With little funds and inadequate devolution from the UT, PRIs have been reduced to simple agents of higher level administration. The biggest disappointment has been the tussle between elected representative and UT administration;

9. Last but not least is the issue of account statement and their audits. Accountability of public funds is at the heart of sound public finance. Not enough progress has been made in this regard. In the $21^{\text {st }}$ century, with a robust system of PRIs, India can march towards achieving the objectives mentioned in the Indian constitution to achieve vibrant democracy;

10. The digital penetration and connectivity in rural areas in reducing the urban-rural information gap and pushing the administration at the local level to function in an effective way under Bharat Net Project, village Panchayats are connected with Optical Fiber and Wi-Fi spots installed in many villages.

\section{CONCLUSION}

The introduction of PRIs was seen, understandably, as a major step in the direction of grass root democracy. Yet after three decades of its functioning, many feel that much needs to be done, say, by delegating more authority and giving more funds to these institutions so as to create confidence among rural masses. The government must revive the practice of conducting capacity-building classes for elected women Panchayat members if it is really interested in further empowering elected Panchayat functionaries and facilitating the underprivileged to fulfill 
R.V. R. Murthy. Three decades of working Panchayati Raj Institutions (PRIs) in Andaman and Nicobar Islands: issues and challenges.

their commitments to the people. What is needed today is to equip more powers with what they need to ensure the achievement of the twin objectives of economic development and social justice.

Consequent to the 73rd Constitution Amendment Act, political decentralization has taken place in A \& $\mathrm{N}$ Islands where elections have been held regularly. However, progress on fiscal and functional decentralization has been mixed. Urgently require to take steps to devolve funds, functions and functionaries to the PRIs. Further, it is imperative that the PRIs have resources to match the responsibilities placed on them. While State Finance Commission has submitted their recommendations, the UT administration has taken the necessary steps to ensure fiscal viability of the PRIs. Yet, one can be hopeful that the experience of some States and some PRIs within.

\section{REFERENCES}

1. Andaman and Nicobar (Panchayats) Regulation 1994, A \& N Administration, Port Blair

2. Andaman and Nicobar Gazette Extraordinary No. 348, dated: November 2, 2000.

3. Bhargava, B.S., Grass root Leadership in Panchayat Raj Institutions, 1979.

4. Singh, Yatindra \& Bhatt, Ashish., Two Decades of PRIs in India: Experiences, Issues, Challenges and Opportunities, 2018.

How to cite this article: R.V. R. Murthy. Three decades of working Panchayati Raj Institutions (PRIs) in Andaman and Nicobar Islands: issues and challenges. International Journal of Research and Review. 2021; 8(12): 338-343. DOI: https://doi.org/10.52403/ijrr.20211242 